\title{
ВПЛИВ ПОЛІТРАВМИ НА ГІСТОФУНКЦІОНАЛЬНІ ЗМІНИ У ТКАНИНАХ МІОКАРДА В ДИНАМІЦІ ПОСТТРАВМАТИЧНОГО ПЕРІОДУ ПРИ ПОЄДНАНІЙ ТРАВМІ НА ФОНІ ГІПОКІНЕТИЧНОГО ОСТЕОПОРОЗУ В ЕКСПЕРИМЕНТІ
}

\author{
ФГ. В. Стойкевич, Х. В. Погорецька, К. М. Дуда, О. І. Лебідь, В. Р. Мачоган
}

Тернопільський національний медичний університет імені І. Я. Горбачевського МОЗ України

PEЗЮME. В XXI столітті набула особливої актуальності проблема надання допомоги постраждалим із поєднаною травмою, оскільки саме наслідки тяжкої механічної травми є головною причиною смертності осіб молодого працездатного віку. Численні патоморфологічні дослідження довели, що тяжка поєднана травма здійснює значний вплив на роботу всіх внутрішніх органів та систем.

Мета роботи - вивчити вплив політравми на структурні зміни в тканинах міокарда в динаміці посттравматичного періоду у тварин з гіпокінетичним остеопорозом.

Матеріал і методи. Експерименти виконано на 42 нелінійних білих щурах-самцях масою 200-220 г. У першій серії експериментів у тварин викликали гіпокінетичний остеопороз за методом Z. Kundurovich, через 2 місяці моделювали політравму. У другій серії аналогічно травмували тварин без остеопорозу. Тварин виводили 3 експерименту на 10, 20 та 30-ту доби. Для гістологічного дослідження забирали тканини міокарда, їх структуру вивчали у нормі, а також характер і глибину морфологічних змін після модельованої політравми.

Результати. На 10-ту добу експерименту у тварин без остеопорозу зміни в міокарді проявлялись розладами кровообігу та вогнищевими дистрофічними змінами. На 20-ту добу експерименту у тварин без остеопорозу спостерігали такі жзміни, як і на 10-ту добу. На 10-ту добу після політравми у тварин з гіпокінетичним остеопорозом у міокарді також мали місце незначні розлади кровообігу та вогнищеві дистрофічні зміни. Як і в групі тварин без остеопорозу, на 20-ту добу експерименту у тварин з остеопорозом суттєвих змін у міокарді, порівняно з 10-ю, не було помічено. На 30-ту добу у тварин без остеопорозу запально-дистрофічні зміни мали тенденцію до зниження. Проте у тварин з остеопорозом на 30-ту добу в міокарді виникають поодинокі дистрофічно-некротичні зміни кардіоміоцитів, набряк строми із вираженими клітинними інфільтратами.

Висновки. Політравма супроводжується гістологічними відхиленнями в міокарді, які більш виражені у тварин із гіпокінетичним остеопорозом у всі терміни спостереження. На 30-ту добу в міокарді виникають поодинокі зміни, які вказують на формування під впливом остеопорозу патогенних механізмів синдрому вторинного загострення політравми.

КлючовІ СлОВА: політравма; гіпокінетичний остеопороз; міокард; регенерація; кардіоміоцити.

Вступ. Гіпокінезія - обмеження рухливості, що зумовлюється способом життя, особливостями професійної діяльності, довготривалим перебуванням у ліжку в період захворювання, механічною фіксацією суглобів (гіпсова пов'язка, скелетне витягнення) і супроводжується у ряді випадків дефіцитом м'язового навантаження (гіподинамія) [1]. Цей стан веде до зменшення навантаження на органи та системи, розвитку гіпокінетичного остеопорозу. Тривала гіпокінезія значно погіршує стан серця, що проявляється у підвищенні частоти серцевих скорочень, зміні структури серцевого циклу, зниженні об'єму крові у процесі кожної систоли. Поступово зменшується загальний об'єм крові, що циркулює по серцево-судинній системі, відбувається його перерозподіл.

У XXI столітті набула особливої актуальності проблема надання допомоги постраждалим із поєднаною травмою, оскільки саме наслідки тяжкої механічної травми $\epsilon$ головною причиною смертності осіб молодого працездатного віку $[2,3,4]$.

Численні патоморфологічні дослідження довели, що тяжка поєднана травма здійснює значний вплив на роботу всіх внутрішніх органів та систем. Проте в доступній літературі повною мірою не висвітлено зміни в серцево-судинній системі після тяжкої травми в ранні терміни посттравматичного періоду на фоні гіпокінетичного остеопорозу.

Мета дослідження - вивчити вплив політравми на структурні зміни у тканинах міокарда в динаміці посттравматичного періоду у тварин 3 гіпокінетичним остеопорозом.

Матеріал і методи дослідження. Експерименти виконано на 42 нелінійних білих щурахсамцях масою 200-220 г. У першій серії експериментів у тварин викликали гіпокінетичний остеопороз за методом Z. Kundurovich (1989) шляхом накладання на тіло тварини гіпсового корсета, що суттєво знизило рухову активність [5]. Через 2 місяці корсет знімали й у тварин моделювали політравму спеціально розробленим способом шляхом пошкодження двох кісткових сегментів: стегна і нижньої щелепи [6].

У другій серії аналогічно травмували тварин без остеопорозу. Контрольну групу склали інтактні тварини. Нанесення травм здійснювалося в умовах тіопентало-натрієвого знеболювання (40 г·К $\left.{ }^{-1}\right)$. 
Огляди літератури, оригінальні дослідження, погляд на проблему, випадок з практики, короткі повідомлення

Тварин виводили з експерименту на 10, 20 та 30-ту доби в умовах тіопентало-натрієвого знеболювання. Для гістологічного дослідження забирали тканини міокарда, які фіксували в 10 \% нейтральному розчині формаліну з наступним ущільненням у парафіні. Отримані на санному мікротомі зрізи фарбували гематоксиліном та еозином, за якими вивчали структуру досліджуваних тканин у нормі, а також характер і глибину морфологічних змін після модельованої політравми. Використовували мікроскоп лОМО Биолам И і систему цифрового виводу зображень гістологічних препаратів. При вивченні морфологічної організації досліджуваних органів звертали увагу на зміни паренхіми й основних структурних компонентів.

Результати й обговорення. При гістологічному дослідженні тканини міокарда у тварин без остеопорозу на 10-ту добу експерименту було виявлено слабовиражене кровонаповнення судин артеріального типу в епікарді та незначне розширення і повнокров'я судин венозного типу. Поряд із цим спостерігали слабкий периваскулярний набряк та поодинокі діапедезні крововиливи. В окремих полях зору спостерігались поліморфноклітинні елементи. Перивазальна строма була дещо розрихлена набряком, який поширювався на міжклітинні простори, дезінтегруючи м'язовий пласт. Клітинні інфільтрати були незначними, локалізувались як периваскулярно, так і в стромі міокарда. Крім того, в окремих тварин можна було виявити крововиливи, які локалізувались у товщі міокарда.

Строма була вираженою помірно, дещо розрихлена, містила поодинокі еритроцити та поліморф- ні клітини. Окремі судини строми дещо розширювались, були нерівномірно кровонаповнені, мав місце слабовиражений периваскулярний набряк.

Кардіоміоцити в більшості полів зору візуалізувались добре. Проте в окремих тварин у товщі міокарда виявляли поодинокі клітини з оптично порожньою цитоплазмою - осередковим внутрішньоклітинним міоцитолізом та пікнотично зміненими ядрами, що свідчило про наявність вогнищевих дистрофічно-некротичних змін.

На 20-ту добу експерименту у тварин без остеопорозу спостерігали такі ж зміни, як і на 10-ту добу. Мало місце зменшення коливання патологічних відхилень у бік зниження.

При гістологічному дослідженні тканини міокарда у тварин з остеопорозом (рис. 1) на 10-ту добу експерименту нами було виявлено помірно виражене кровонаповнення судин артеріального типу в епікарді та незначне розширення і повнокров'я судин венозного типу.

Водночас мали місце слабовиражений периваскулярний набряк та поодинокі діапедезні крововиливи. В окремих полях зору спостерігали поліморфноклітинні елементи. Перивазальна строма була дещо розрихлена набряком, який поширювався і на міжклітинні простори. Клітинні інфільтрати були незначними, локалізувались як периваскулярно, так і в стромі міокарда. Крім того, в окремих тварин можна було виявити поодинокі крововиливи, які локалізувались у товщі міокарда.

Строма була виражена помірно, дещо розрихлена, містила поодинокі еритроцити та поліморфні клітини. Окремі судини строми дещо розширю-

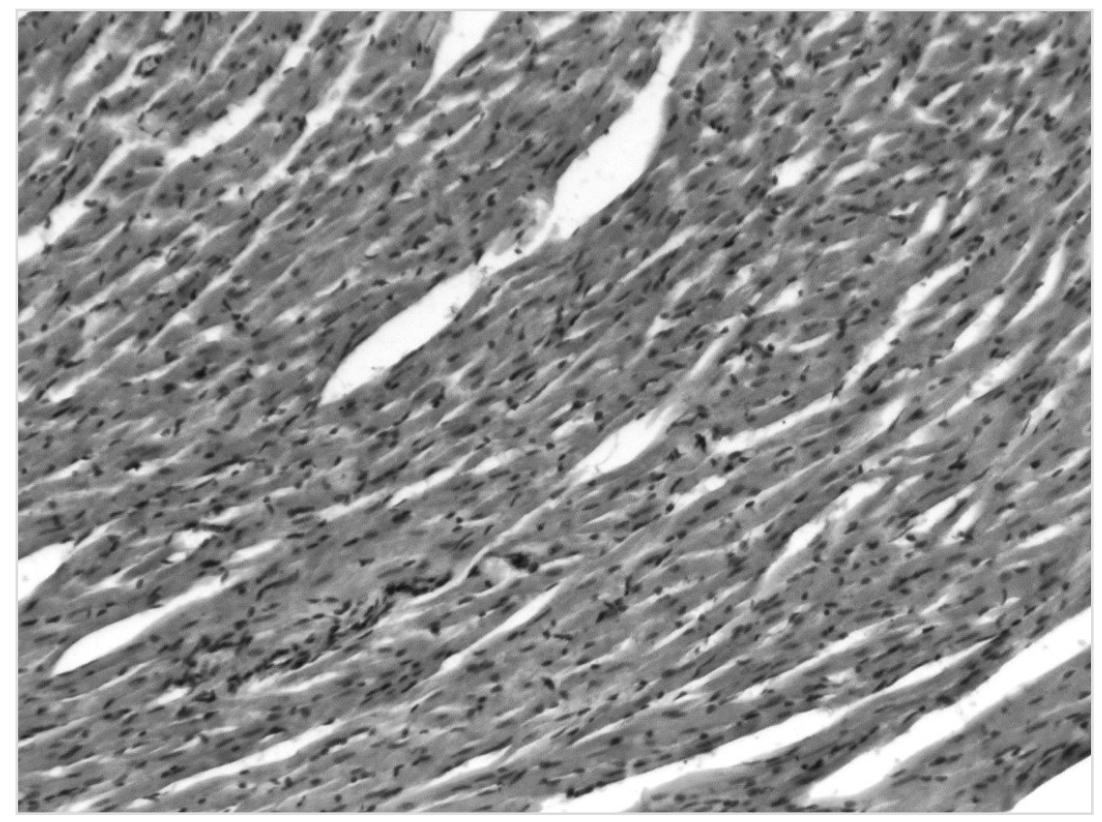

Рис. 1. Гістологічна структура міокарда тварини на 10-ту добу експерименту при моделюванні політравми на фоні остеопорозу. Забарвлення гематоксиліном та еозином. ×200. 
Огляди літератури, оригінальні дослідження, погляд на проблему, випадок з практики, короткі повідомлення вались, були нерівномірно кровонаповнені, мав місце слабовиражений периваскулярний набряк.

Кардіоміоцити в більшостіполів зору візуалізувались добре. Проте, в окремих полях зору в товщі міокарда виявляли поодинокі клітини із осередковим внутрішньоклітинним міоцитолізом та пікнотично зміненими ядрами, що свідчило про наявність вогнищевих дистрофічно-некротичних змін.

Як і в групі тварин без остеопорозу, на 20-ту добу експерименту у тварин з остеопорозом суттєвих змін у міокарді, порівняно з 10-ю, не було помічено. Розвивались незначні розлади кровообігу у вигляді повнокров'я судин, периваскулярного набряку та незначних дрібновогнищевих дистрофічних змін.

При гістологічному дослідженні тканини міокарда на 30-ту добу експерименту було виявлено помірне кровонаповнення судин артеріального типу в епікарді та розширення і повнокров'я судин венозного типу у тварин без остеопорозу. Водночас спостерігали незначний периваскулярний набряк. Кардіоміоцити в більшості полів зору візуалізувались добре.

Проте, в окремих полях зору в товщі міокарда виявляли поодинокі клітини із ознаками вогнищевих дистрофічних змін. В ендокарді виявляли поодинокі скупчення лімфо-гістіоцитів. Поряд із цим виявляли помірну перицелюлярну лімфогістіоцитарну інфільтрацію.

Перивазальна строма була дещо розрихленою набряком, який поширювався й на міжклітинні простори, дезінтегруючи м'язовий пласт. Клітинні інфільтрати були поодинокими, локалізувались як периваскулярно, так і в стромі міокарда. Строма була слабовираженою, розрихленою, містила поодинокі еритроцити та поліморфні клітини. Окремі судини строми дещо розширювались, були нерівномірно кровонаповненими, мав місце незначний периваскулярний набряк.

При гістологічному дослідженні тканини міокарда у тварин з гіпокінетичним остеопорозом було виявлено слабовиражене кровонаповнення судин артеріального типу в епікарді та незначне розширення і повнокров'я судин венозного типу.

У той же час спостерігали слабкий периваскулярний набряк і поодинокі діапедезні крововиливи та поліморфноклітинні елементи. Перивазальна строма була різко розрихлена набряком, який поширювався і на міжклітинні простори, дезінтегруючи м'язовий пласт. Клітинні інфільтрати локалізувались як периваскулярно, так і в стромі міокарда. Крім того, в окремих полях зору виявляли крововиливи, які локалізувались у товщі міокарда.

Строма була вираженою помірно, дещо розрихлена, містила поодинокі еритроцити та поліморфні клітини. Окремі судини строми дещо розширювались, були нерівномірно кровонаповнені, мав місце слабовиражений периваскулярний набряк.

Кардіоміоцити в більшості полів зору візуалізувались добре. Проте, в окремих тварин у товщі міокарда виявляли поодинокі клітини з оптично порожньою цитоплазмою - осередковим внутрішньоклітинним міоцитолізом та пікнотично зміненими ядрами, що свідчило про наявність вогнищевих дистрофічно-некротичних змін (рис. 2).

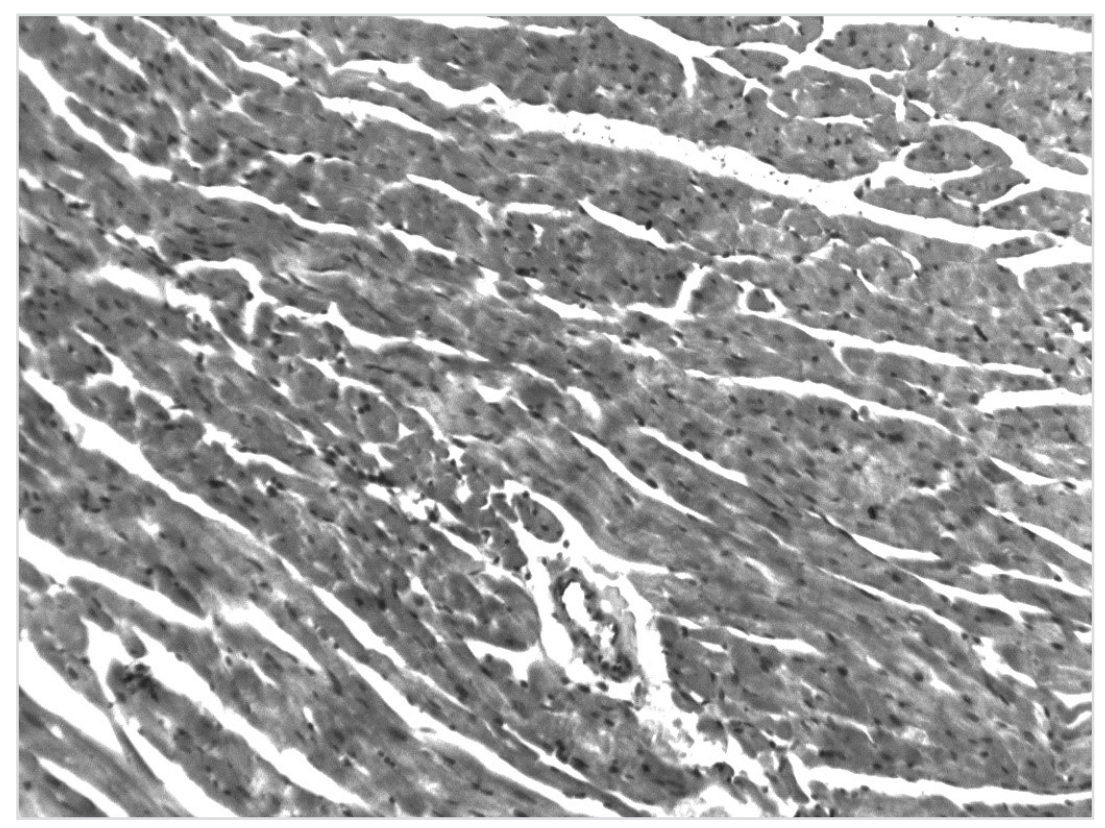

Рис. 2. Гістологічна структура міокарда тварини на 30-ту добу експерименту при моделюванні політравми (на фоні остеопорозу). Забарвлення гематоксиліном та еозином. $\times 200$. 
Окремі ділянки із некротично зміненими кардіоміоцитами були оточені поліморфноклітинними інфільтратами. В ендокарді виявляли поодинокі скупчення лімфо-гістіоцитів.

Отримані результати вказують на те, що політравма супроводжується вираженими запально-дисторфічними змінами в усіх структурах міокарда. У свою чергу, гіпокінетичний остеопороз посилює патологічні зміни, і ця тенденція виявлена нами й в інших органах та системах $[7,8]$.

Характерною рисою більшості отриманих результатів на тлі гіпокінетичного остеопорозу $є$ коливальні відхилення з періодом наближення показників у бік контрольної групи на 10, 20-ту доби та з наступним повторним і ще глибшим відхиленням на 30-ту добу. Отже, гіпокінетичний остеопороз істотно впливає на динаміку політравми, облему, випадок з практики, короткі повідомлення провокуючи хвилю загострення на 30-ту добу експерименту [9].

Висновки. Таким чином, політравма супроводжується гістологічними відхиленнями в міокарді, які більш виражені у тварин із гіпокінетичним остеопорозом у всі терміни спостереження. Проте на 30-ту добу в міокарді виникають поодинокі дистрофічно-некротичні зміни кардіоміоцитів, набряк строми із вираженими клітинними інфільтратами, що вказує на формування під впливом остеопорозу патогенних механізмів синдрому вторинного загострення політравми.

Перспективи подальших досліджень. У перспективі доцільно розробити методичні підходи до корекції виявлених порушень у міокарді як в умовах самої політравми, так і її поєднання 3 гіпокінетичним остеопорозом.

\section{ЛІТЕРАТУРА}

1. Смирнов А. В. Гиподинамия и гипокинезия факторы риска для лиц с ограниченными возможностями и отклонениями в состоянии здоровья : материалы XVIII Всероссийской научно-практической конференции «Актуальные вопросы физической культуры и спорта» / А. В. Смирнов. - Томск, 2015. - С. 122-124.

2. Иноземцев Е. О. Актуальные вопросы хирургии сочетанных повреждений (по материалам публикаций журнала «Травма»)/ Е. О. Иноземцев, Е. Г. Грегорьев, К. А. Апарцин // Политравма. - 2017. - № 1. - С. 6-11.

3. Агаджаниян В. В. Госпитальная летальность при политравме и основные направления ее снижения / В. В. Агаджаниян, С. А. Кравцов, А. В. Шаталин // Политравма. - 2015. - № 1. - С. 6-15.

4. Козопас В. С. Травма таза при політравмі: догоспітальний етап надання допомоги / В. С. Козопас // Травма. - 2014. - № 15 (1). - С. 96-99.

5. Kundurovich Z. The effects of gypcin cuff streess provocation on the level of Ca and the body weight in rats / Z. Kundurovich, M. Hynjicevich, A. Causevich // Arch. Biol. Yugosl. - 1989. - No. 27 (7). - P. 79-80.

\section{REFERENCES}

1. Smirnov, A.V. (2015). Gipodinamiya i gipokineziya faktory riska dlya lits s ogranichennymi vozmozhnostyami i otkloneniyami v sostoyanii zdorovya [Hypodinemia and hypokinesia are risk factors for persons with disabilities and abnormalities in health status]. Proceedings of the XVIII All-Russian Scientific and Practical Conference: "Aktualnyye voprosy fizicheskoy kultury i sporta" - "Actual Issues of Physical Culture and Sports". (pp. 122-124). Tomsk. [in Russian].

2. Inozemtsev, Ye.O., Gregoryev, Ye.G., \& Apartsin, K.A. (2017). Aktualnyye voprosy khirurgii sochetannykh povrezhdeniy (po materialam publikatsiy zhurnala "Travma") [Topi-
6. Гудима А. А., Федірко Г. В., винахідники; ДВНЗ “Терн. держ. мед. унів. ім. І.Я. Горбачевського МОЗ Укр.", патентовласник. Спосіб моделювання політравми. Патент України № ч 2012 13431. 2012 лист. 26.

7. Федірко Г. В. Особливості патоморфогенезу пошкодженої стегнової кістки в динаміці посттравматичного періоду у тварин з політравмою і гіпокінетичним остеопорозом / Г. В. Федірко, А. А. Гудима, В. В. Підгірний // Український журнал екстремальної медицини імені Г. О. Можаєва. - 2013. - № 14 (2). - С. 38-42.

8. Комплексне експериментальне дослідження іммобілізаційної моделі остеопорозу / Л. Я. Ковальчук, М. С. Гнатюк, С. І. Сміян [та ін.] // Вісник наукових досліджень. - 2000. - № 1. - С. 81-84.

9. Марценюк В. П. Про нелінійну динамічну систему реконструкції кісткової тканини / В.П.Марценюк, І. В. Жулкевич, О. Я. Ковальчук // Вісник Київського університету: Серія фізико-математичні науки. - 2001. № 4. - С. 292-298.

cal issues of surgery of combined injuries (based on the publications of the journal "Trauma"]. Politravma - Polytrauma, 1, 6-11 [in Ukrainian].

3. Agadzhaniyan, V.V., Kravtsov, S.A., \& Shatalin, A.V. (2015). Gospitalnaya letalnost pri politravme i osnovnyye napravleniya yeye snizheniya [Hospital lethality with polytrauma and the main directions of its decrease]. Politravma-Polytrauma, 1, 6-16 [in Russian].

4. Kozopas, V.S. (2014). Travma taza pry politravmi: dohospitalnyi etap nadannia dopomohy [Trauma of the pelvis under polytrauma: pre-hospital stage of rendering of help]. Travma - Trauma, 15 (1), 96-99 [in Ukrainian]. 
Огляди літератури, оригінальні дослідження, погляд на проблему, випадок з практики, короткі повідомлення

5. Kundurovich, Z. (1989). The effects of gypcin cuff streess provocation on the level of $\mathrm{Ca}$ and the body weight in rats. Arch. Biol. Yugosl., 27 (7), 79-80.

6. Hudyma, A.A., \& Fedirko, H.V., vynakhidnyky (2015). I. Horbachevsky Ternopil State Medical University", patentovlasnyk. Sposib modeliuvannia politravmy [Method for modeling polytrauma]. Patent of Ukraine No. u 2012 13431. 2012 lyst.26 [in Ukrainian].

7. Fedirko, H.V., Hudyma, A.A., \& Pidhirnyi, V.V. (2013). Osoblyvosti patomorfohenezu poshkodzhenoi stehnovoi kistky $v$ dynamitsi posttravmatychnoho periodu u tvaryn z politravmoiu i hipokinetychnym osteoporozom [Peculiarities of the pathomorphogenesis of damaged femur in the dynamics of the post-traumatic period in animals with polytrauma and hypokinetic osteoporosis]. Ukrainskyi zhurnal ekstremalnoi medytsyny imeni H.O. Mozhaieva -
H.O. Mozhaev Ukrainian Journal of Extreme Medicine, 14 (2), 38-42 [in Ukrainian].

8. Kovalchuk, L.Ya., Hnatiuk, M.S., Smiyan, S.I., Zhulkevych, I.V., Masyk, O.M., Hudyma, A.A., \& Lisnychuk, N.Ye. (2000). Kompleksne eksperymentalne doslidzhennia imobilizatsiinoi modeli osteoporozu [Complex experimentalmental study of osteo-defeat imo-bilization model]. Visnyk naukovykh doslidzhen - Bulletin of Scientific Researches, 1, 81-84 [in Ukrainian].

9. Martseniuk, V.P., Zhulkevych, I.V., \& Kovalchuk, O.Ya. (2001). Pro neliniinu dynamichnu systemu rekonstruktsii kistkovoi tkanyny [On nonlinear dynamic system of bone tissue reconstruction]. Visnyk Kyivskoho universytetu: Seriia fizyko-matematychni nauky - Bulletin of the University of Kiev: Series of Physical and Mathematical Sciences, 4, 292-298 [in Ukrainian].

\title{
ВЛИЯНИЕ ПОЛИТРАВМЫ НА ГИСТОФУНКЦИОНАЛЬНЫЕ ИЗМЕНЕНИЯ В ТКАНЯХ МИОКАРДА В ДИНАМИКЕ ПОСТТРАВМАТИЧЕСКОГО ПЕРИОДА ПРИ СОЧЕТАННОЙ TРАВМЕ НА ФОНЕ ГИПОКИНЕТИЧЕСКОГО ОСТЕОПОРОЗА В ЭКСПЕРИМЕНТЕ
}

\author{
๑Г. В. Стойкевич, К. В. Погорецкая, Е. М. Дуда, О. И. Лебедь, В. Р. Мачоган
}

Тернопольский национальный медицинский университет имени И. Я. Горбачевского Мз Украины

PEЗЮМЕ. В XXI веке приобрела особую актуальность проблема оказания помощи пострадавшим с сочетанной травмой, поскольку именно последствия тяжелой механической травмы являются главной причиной смертности лиц молодого трудоспособного возраста. Многочисленные патоморфологические исследования показали, что тяжелая сочетанная травма оказывает значительное влияние на работу всех внутренних органов и систем.

Цель - изучить влияние политравмы на структурные изменения в тканях миокарда в динамике посттравматического периода у животных с гипокинетическим остеопорозом.

Материалы и методы. Эксперименты выполнены на 42 нелинейных белых крысах-самцах массой 200-220 г. В первой серии экспериментов у животных вызывали гипокинетический остеопороз методом Z. Kundurovich, через 2 месяца моделировали политравму. Во второй серии аналогично травмировали животных без остеопороза. Животных выводили из эксперимента на 10, 20 и 30-е сутки. Для гистологического исследования забирали ткани миокарда, их структуру изучали в норме, а также характер и глубину морфологических изменений после моделируемой политравмы.

Результаты. На 10-е сутки эксперимента у животных без остеопороза изменения в миокарде проявлялись расстройствами кровообращения и очаговыми дистрофическими изменениями. На 20-е сутки эксперимента у животных без остеопороза наблюдались такие же изменения, как и на 10-е сутки. На 10-е сутки после политравмы у животных с гипокинетическим остеопорозом в миокарде также имели место незначительные расстройства кровообращения и очаговые дистрофические изменения. Как и в группе животных без остеопороза, на 20-е сутки эксперимента у животных с остеопорозом существенных изменений в миокарде, по сравнению с 10, не было замечено. На 30-е сутки у животных без остеопороза воспалительно-дистрофические изменения имели тенденцию к снижению. Однако у животных с остеопорозом на 30-е сутки в миокарде возникают одиночные дистрофическинекротические изменения кардиомиоцитов, отек стромы с выраженными клеточными инфильтратами.

Выводы. Политравма сопровождается гистологическими отклонениями в миокарде, которые более выражены у животных с гипокинетическим остеопорозом во все сроки наблюдения. На 30-е сутки в миокарде возникают одиночные изменения, указывающие на формирование под влиянием остеопороза патогенных механизмов синдрома вторичного обострения политравмы.

КЛЮЧЕВЫЕ СЛОВА: политравма; гипокинетический остеопороз; миокард; регенерация; кардиомиоциты. 
Огляди літератури, оригінальні дослідження, погляд на проблему, випадок з практики, короткі повідомлення

INFLUENCE OF POLYTRAUMA ON HISTOFUNCTIONAL CHANGES IN MYOCARDIAL TISSUES IN DYNAMICS OF A POSTTRUMATIC PERIOD IN A COMBINED TRAUMA IN THE EXPERIMENT IN THE FIELD OF HYPOKINETIC OSTEOPOROSIS

\section{○H. V. Stoikevych, Kh. V. Pohoretska, K. M. Duda, O. I. Lebid, V. R. Machohan I. Horbachevsky Ternopil National Medical University}

SUMMARY. In the 21st century, problem of assisting victims with combined trauma has become particularly relevant, since it is the effect of mechanical trauma that are the main cause of mortality in young and able-bodied people. The pathomorfological researches shown that severe combined trauma has a biggest influence on the functioning of all internal organs and systems.

The aim of the work - to study the effect of polytrauma on structural changes in myocardial tissues in the posttraumatic period in animals with hypokinetic osteoporosis.

Material and Methods. Experiments were performed on 42 non-linear white male rats weighing 200-220 g. In the first series of experiments in animals, hypokinetic osteoporosis was induced by the method of Z. Kundurovich, after 2 months of modeling a polytrauma. In the second series, animals without osteoporosis were similarly injured. Animals were extracted from the experiment for 10, 20 and 30 days. For histological examination, the tissues of the myocardium were removed, their structure was studied normally, as well as the nature and depth of morphological changes after the simulated polytrauma.

Results. At the 10 th day of the experiment in animals without osteoporosis changes in the myocardium were manifested by circulatory disorders and focal degenerative changes. At the 20th day of the experiment in animals without osteoporosis, the same changes were observed as in the 10th day. At the 10th day after the polytrauma in animals with hypokinetic osteoporosis in the myocardium, minor circulatory disorders and focal degenerative changes also occurred. As in the group of animals without osteoporosis, in the 20th day of experiment in animals with osteoporosis, significant changes in the myocardium were not observed in comparison with the 10th. In the 30th day, in animals without osteoporosis, inflammatory-dystrophic changes tended to decrease. However, in animals with osteoporosis for 30 days in the myocardium, there are isolated dystrophic-necrotic changes of cardiomyocytes, swelling of the stroma with pronounced cellular infiltrates.

Conclusions. Polytrauma is accompanied by histological abnormalities in the myocardium, which are more pronounced in animals with hypokinetic osteoporosis in all terms of observation. On the 30th day in the myocardium, there are some changes that indicate the formation of pathogenic mechanisms of the secondary exacerbation of polytrauma under the influence of osteoporosis.

KEY WORDS: polytrauma; hypokinetic osteoporosis; myocardium; regeneration; cardiomyocytes.

Отримано 07.11.19 